\title{
Franchises and New Business Strategy
}

\section{Srimanta Ghosh}

\begin{abstract}
In this paper present a conceptual framework to separate and relate the concepts of franchises and new business model and how it operates and creates value for its stakeholders. The purpose of this article is to describe the significance of franchise and new business models. This article also explores the connections with business strategy and innovation management. This paper also delivers a clear distinction between strategy and tactics for franchise and new business model.
\end{abstract}

Keywords

Business enterprise;
Business strategy;
Business ownership;
Franchises;

New business.

\section{INTRODUCTION}

Franchising is one of the major sources of the company growth and continuous business development [1]. Recently many talented entrepreneurs enter in the business main stream becoming a franchisee before their independent business [2]. The definition of franchisee is nothing but opening branch of a company which is well established in the market and the profit is divided between the seller and the company owner [3]. A new business is the one an individual or a group of individual share their own ideas and with that ideas they frame the strategies and start a new firm either with their own hand investment or by taking some loans from banks etc. [4]. Here for the new business to be started owner have to work a lot by making advertisements and it should reach the people to the maximum then only $r$ product will reach the entire society [5].

Starting a business of own is not an easy task because the idea which has should be approved by higher authorities, patent works, filings and many more. The idea should be $\mathrm{r}$ own and it should not be from some others [6]. If the project is approved then investment is the main criteria where investor has to invest a lot for the growth of the firm [7]. For established any business first requirement to avail a land for starting own company. Then need man power for that, then need raw materials, and then plan for that, then finally need the finance [8]. The problem in starting a new business is that if gain or lose i.e., the profit and loss of the company is a burden on if $r$ company gains profit then it's a benefit for the investor and if the company loss profit then it's a burden for him because he have to repay the loss. Either explicitly or implicitly employs a preferable business model and strategy that describes the process of the different value creation, delivery mechanism whenever any business enterprise is established.

Business Model Strategy which is also consider as the 'logic of the firm' [9]. One can find that in simple competitive circumstances there is a one-to-one mapping between the strategy plan and business enterprises.

\section{COMPARISON BETWEEN NEW BUSINESS AND FRANCHISES}

The thing about the new business is investor have to take care of everything expenditure, gain or loss, profit or loss, growth and development. Whereas a franchisee is the one where already a well-established company is giving all the necessary things like equipment's, land, ownership, dealership etc., Here in a franchisee the profit will not be equally shared by the owner and the dealer whereas they will make an agreement by which they frame certain rules and regulations [10]. The agreement will be such that if a company is giving all the equipment's to the franchisee, land and some other things, so here the money which was invested on the equipment's and the land have to be re-paid by the franchisee to the company's owner [11]. The rest of the investments like man power and other things should be taken care of the franchisee. The concepts of franchises and business model may differ when there are important eventualities on which a well-organised strategy must be required to open a new business. Different circumstance and condition may be paid attention for possible expansion of new business because strategy and business model are different for different situation [12].

Franchiser cannot increase their business or business outlet like an independent company, but most advantages is that total reliability falls upon the parent company.

Different method of business ownership will have benefits and drawbacks. There are no confirmed and establish methods of success in any kind of business 
model. The success key of any business model is totally depends on the strong team and good team leader, whether it be different employees and family in a business opportunity, or the dealer and co-dealer in a franchise model. Franchises offer more advantage in comparison with business and it sustains and also provides more security system. In many different occasion franchisors offer different training schemes and support with things related with the management of the arriving of new products, accounts handling mechanism, sales, advertising, customer care, service centre and many more. These sorts of things may well be included in the price of the franchise fee.

\section{Franchises OR NeW Business}

Generally investor prefer to purchase a franchisee rather than opening a new business and according to me franchisee is the best idea one should go for because in a new business if idea is perfect gain profit positive to the maximum or if lose it will go to the negative end to the maximum. Thus franchisee is the best idea than a new business.

The agreement may be like $48 \%$ for franchisee and $52 \%$ for the owner or it may be $60 \%-40 \%$, or it may be $40 \%-60 \%$ depends on the agreement which they have signed. Here there is more advantage in franchisee rather than starting a own business because if a loss occurs in a company which is running through franchisee then the loss will be equally shared by the company and the franchisee i.e., if a company have 15 franchisee (15 branches or 15 dealers) then the loss will be equally shared between them so the burden is minimised. Whereas in a new business if a loss happened the entire responsibility lies on for the total loss and has to repay the total loss.

Examples of franchisee are all the companies like car and bike companies have dealerships so that these companies do not directly involve in selling the products whereas they have franchisee companies or the dealers where they take the products of the company and they sell it and the profit will be shared based on the agreement between the owner and the dealer [13]. The agreement will be based on the intelligence of the owner or the franchisee.

When one can find the right business he must take some time to read through all relevant information. A market survey is also essential to perform before investing money. Due to modern advanced technology all the relevant information is available in internet and research the particular business online [14]. One can consult with the other owners of the same or similar business to get their thoughts and opinions, and talk with $r$ advisors to get an outside perspective on the business. Once have made decisions, take the next step knowing that have made the right decision for franchises.

Most of the business organization believe the traditional business format i.e. cash based smooth operation. Basically franchise staffed by family members generally this process reduced starting cost. Franchising is family labour business administration model.

Generally buyers will recognize the brand not the owner of the franchise and the total reputation of the company depends on the parent company. It is parent company responsibility how they improved their reorganization. Own personality always matter to take decision if strong determination to become a well known figure in the business community with creative mind and want to try new ways of running a business, the concept of franchises probably is not better decision than starting own business but great chance to gain experience as a business owner. The main criteria of any franchisee setup it must function their business work or business procedures in a certain rules and restrictions which set by the franchiser. The franchisee must control their business operation by instruction set by the franchiser and this is totally commission basics. [15] A franchise offers the various advantage of operating under the banner of a previously reputable business. The ideas, the brand, the operating techniques and much more are already tried and tested and in place ready to be implemented again and again at a new location as each franchisee takes up the mantle.

The direct outlet stores before opening and operating franchise, must exhibit sufficient pricing power the franchisor and also the franchisee. This would abolish commodity type yield where there is no pricing other than advertising at the lowest cost or minimum cost. Generally speaking, pricing power can be defined as the power to increase prices without lessening the demand of the particular product. The lack of sufficient pricing power can result in franchisees deteriorating through be exhausted and overlong hours.

Too often compromises are complete in lease terms. Issues such as rental fee, shelling term, alternative, cost of living adjustments, non-compete provisions [16]; signage and common charges all need to be cautiously negotiate with different terms that will create profitable stores. While it is the franchisees who takes on the rent obligation, their default become 
larger problems in the form of franchisee lawsuits and tarnished public image.

\section{CONClusion}

A business model is systematically representing different strategy to be implemented in new business model and franchise. Different management's hypothesis regarding the requirement of customer's demands, how they want it fulfil their desire and how the business model can systematize to best fitted those needs and get paid for extra services and also gain some profit from their business.

\section{REFERENCES}

[1] Achtenhagen, L., Brunninge, O., \& Melin, L. (2017). Patterns of Dynamic Growth in MediumSized Companies: Beyond the Dichotomy of Organic Versus Acquired Growth. Long Range Planning, 50(4), 457-471.

[2] Rosa, P. (2003). Hardly Likely to Make the Japanese Tremble' The Businesses of Recently Graduated University and College 'Entrepreneurs. International Small Business Journal, 21(4), 435-459.

[3] Markides, C. (1998). Strategic innovation in established companies. Sloan Management Review, 39(3), 31.

[4] A new business is the one an individual or a group of individual share their own ideas and with that ideas they frame the strategies and start a new firm either with their own hand investment or by taking some loans from banks etc.

[5] Faltin, G. (2001). Creating a culture of innovative entrepreneurship. Journal of International Business and Economy, 2(1), 123-140.

[6] Dennett, D. C. (1995). Darwin's dangerous idea. The Sciences, 35(3), 34-40.

[7] Geng, Y., \& Hengxin, Z. (2009). Industrial park management in the Chinese environment. Journal of Cleaner Production, 17(14), 1289-1294.

[8] Geng, Y., \& Hengxin, Z. (2009). Industrial park management in the Chinese environment. Journal of Cleaner Production, 17(14), 1289-1294.

[9] Casadesus-Masanell, R., \& Ricart, J. E. (2010). From strategy to business models and onto tactics. Long range planning, 43(2), 195-215.

[10] Roy, A., \& Mukherjee, K. (2017). Entrepreneurial Education in India. International Journal of Advanced Engineering and Management, 2(1), 15-20.
[11] Richardson, B. J., \& Cragg, W. (2010). Being virtuous and prosperous: SRI's conflicting goals. Journal of business ethics, 92, 21-39.

[12] Mukherjee, M. (2017). Innovation and System Design. International Journal of Advanced Engineering and Management, 2(2), 29-32.

[13] Frazier, G. L., \& Rody, R. C. (1991). The use of influence strategies in interfirm relationships in industrial product channels. the Journal of Marketing, 52-69.

[14] Martin, L. M., \& Matlay, H. (2003). Innovative use of the Internet in established small firms: the impact of knowledge management and organisational learning in accessing new opportunities. Qualitative Market Research: An International Journal, 6(1), 18-2.

[15] Emerson, R. W. (2010). Franchise encroachment. American Business Law Journal, 47(2), 191-290.

[16] Kobayashi, B. H., \& Ribstein, L. E. (2011). Law's information revolution. Ariz. L. Rev., 53, 1169.

Author

Srimanta Ghosh

Dept. of EME, Global Institute of Engineering and Management, India

Email id srimanta.ghosh24@gmail.com

Srimanta Ghosh, "Franchises and New Business Strategy", International Journal of Advanced Engineering and Management, Vol. 2, No. 8, pp. 193-195, 2017. DOI: https://doi.org/10.24999/IJOAEM/02080044 